28. SHEPARD, J.H. 2002. Response to "Some new genus names for BC butterflies". Boreus 21(2):14.

29. THORMIN, T.W., N.G. KONDLA \& C.D. BIRD. 1980. Further records of skippers and butterflies from the Milk River-
Lost River area of southeastern Alberta. Blue Jay 38:5-10.

30. TUZOV, V.K. (ed.) 1997. Guide to the Butterflies of Russia and adjacent territories (Lepidoptera, Rhopalocera). Volume 1. Pensoft. Sofia - Moscow. 480 pp.

\title{
DAKOTA SKIPPER (Hesperia dacotae) IN SASKATCHEWAN
}

RONALD R. HOOPER, Box 757, Fort Qu'Appelle, SK S0G 1S0

On July 19, 2001, I collected three male Dakota Skippers (Hesperia dacotae) on a prairie hilltop near Oxbow, Saskatchewan. These were the first known records of this species of butterfly for the province. These males had established territory which they guarded from high perches on top of purple coneflowers (Echinacea angustifolia). When disturbed they would dash off, but later return to the same perches. The Dakota Skipper has previously been taken as far west as Brandon, Manitoba and McKenzie County in western North Dakota.'

In July 2002, Reginald Webster did a Canadian survey in Manitoba and southeastern Saskatchewan of the Dakota Skipper for COSEWIC. ${ }^{2}$ On July 11 , he observed about 22 individuals in the Oxbow area. Three other Dakota Skipper records from Saskatchewan in 2002 were a female collected near Roche Percee on July 1 by Daniel Glaeske; a female collected south of Glen Ewen along the east slope of the Souris River Valley on July 28 by John Kozial; and a worn female collected $5 \mathrm{~km}$ east of Roche Percee on 29 July also by John Kozial.

The identity of our Saskatchewan specimens was confirmed by Ronald Royer of Minot State University who viewed high resolution jpg files of one of the 2001 males
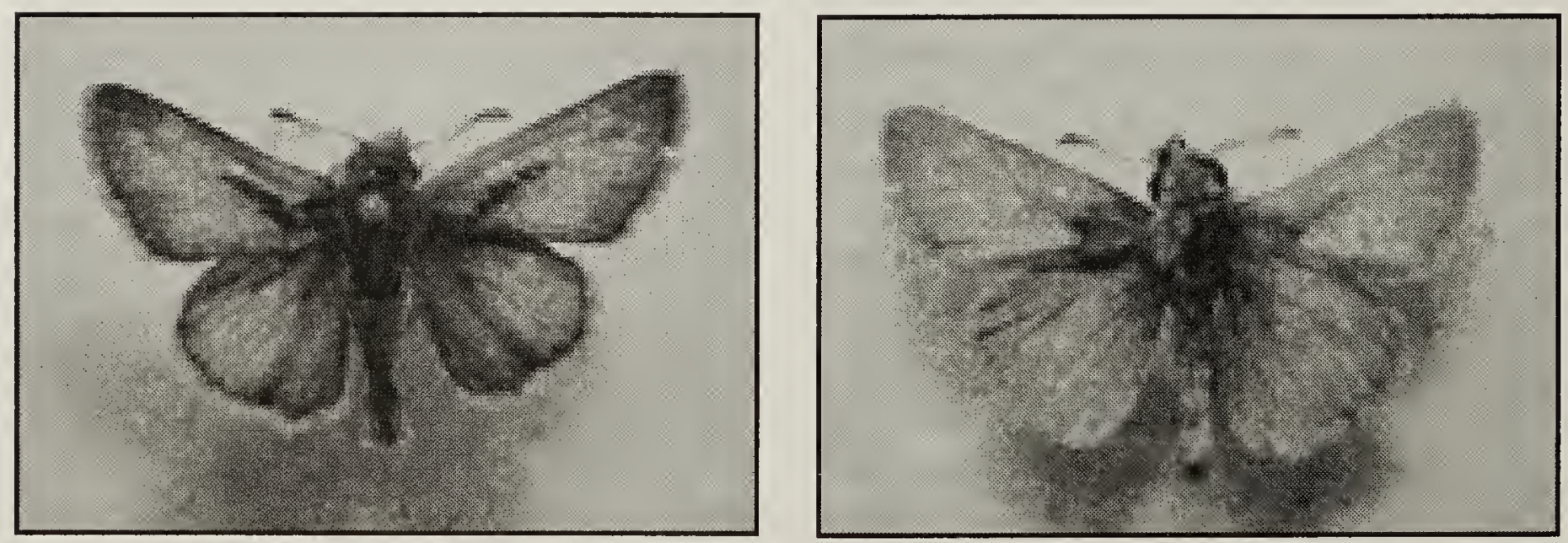

Male Dakota Skipper collected by Ron Hooper at Oxbow, SK on 19 July 2001 (left - dorsal surface, right-ventral surface) / Jeanette Pepper 

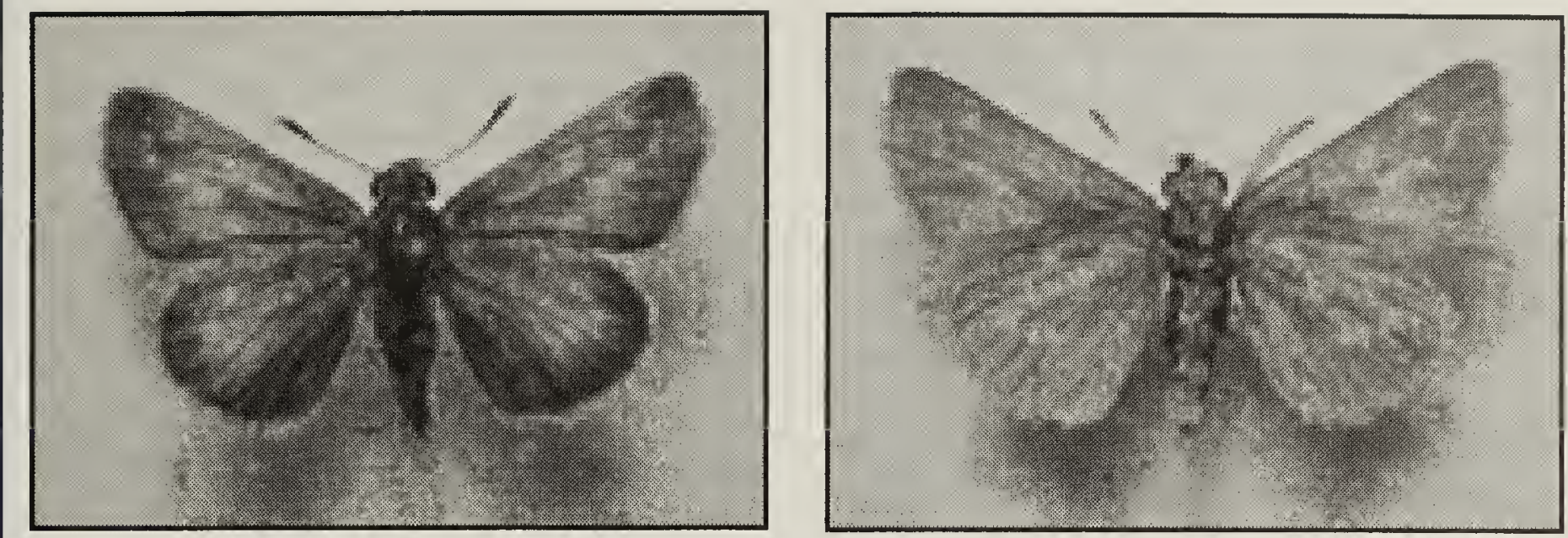

Female Dakota Skipper collected by John Kozial at Glen Ewen on 28 July 2002 (left - dorsal surface, right-ventral surface)/Jeanette Pepper

and the female collected by Daniel Glaeske. He was amazed that they have such a long flight period in Saskatchewan. Perhaps our cold spring had set some of them back for a later emergence in 2002.

The United States population of the Dakota Skipper has been declining, partly because of loss of habitat. Although the species is not immediately threatened or endangered in North Dakota, there are long term threats related to land management practices. Grazing is hard on the species in the drier western parts of its range, probably because of soil compaction and consequent changes in the microhabitat moisture regime. Habitat that is on land that is hayed (which often occurs late in the season) does not degrade as quickly as that on grazed land. (Ron Royer, pers. comm. 22 April 2003). The survey by Reginald Webster in Manitoba shows that it is not in immediate danger in that part of its range, but due to habitat loss it is no longer found in a number of areas where it occurred previously.

Skippers of the genus Hesperia are, on the upper surface, predominantly tawny orange and edged with dark brown in males, and dark brown with tawny orange bands in females. They are from 24 to $32 \mathrm{~mm}$ in wing expanse. On Dakota Skipper males, the dark borders on the upper wing surface are narrower than in most of the other species of the genus. The Nevada Skipper is very narrowly edged with dark on the hind wing but the narrow edging is more even than in the Dakota Skipper, which has edging that is jagged with dark points extending between the veins. Leonard's Skipper (Hesperius leonardus) also has this feature, but is larger and flies later. (Leonard's Skipper was rediscovered near St. Victor by Daniel Glaeske in August 2001.)

On the underside, male and female Dakota Skippers have a tawny brown to light brown ground colour with greatly reduced markings. The lower edge of the forewing is darker than in the other species of Hesperia and the light band of the forewing is more continuous.

Our Saskatchewan butterfly list is now at 158 species.

1. ROYER, R. A. 2003. Butterflies of North Dakota: An Atlas and Guide. Minot State University Science Monograph Number Two. Minot State University. Minot, North Dakota. 192 pp.

2. WEBSTER, R. 2003. COSEWIC Status Report on Dakota Skipper (Hesperia dacotae (Skinner 1911). In preparation. 